\title{
A study on use of animals as traditional medicine by Sukuma Tribe of Busega District in North-western Tanzania
}

Rajeev Vats ${ }^{*}$ and Simion Thomas

\begin{abstract}
Background: Faunal resources have played an extensive range of roles in human life from the initial days of recorded history. In addition to their importance, animals have been acknowledged in religion, art, music and literature and several other different cultural manifestations of mankind. Human beings are acquainted with use of animals for foodstuff, cloth, medicine, etc. since ancient times. Huge work has been carried out on ethnobotany and traditional medicine. Animal and their products are also holding medicinal properties that can be exploited for the benefit of human beings like plants. In Tanzania, many tribal communities are spread all over the country and these people are still totally depended on local customary medicinal system for their health care. In the world Tanzania is gifted with wide range of floral and faunal biodiversity. The use of traditional medicine from animals by Sukuma ethnic group of Busega district is the aim of the present study.

Method: In order to collect the information on ethnozoological use about animal and their products predominant among this tribe in Busega district, a study was carried out from August 2012, to July 2013. Data were collected through semi-structured questionnaire and open interview with 180 (118 male and 62 females) selected people. The people from whom the data were collected comprise old age community members, traditional health practicener, fishermen and cultural officers. The name of animal and other ethnozoological information were documented. Pictures and discussion were also recorded with the help of camera and voice recorder.

Result: A total of 42 various animal species were used in nearly 30 different medicinal purposes including STD, stoppage of bleeding, reproductive disorders, asthma, weakness, tuberculosis, cough, paralysis and wound and for other religious beliefs. It has been noticed that animal used by Sukuma tribe, comprise of seventeen mammals, seven birds, four reptiles, eight arthropods and two mollusks. Some of the protected species were also used as important medicinal resources. We also found that cough, tuberculosis, asthma and other respiratory diseases are the utmost cited disease, as such, a number of traditional medicines are available for the treatment.

Conclusions: The present work indicates that 42 animal species were being used to treat nearly 30 different ailments and results show that ethnozoological practices are an important alternative medicinal practice by the Sukuma tribe living in Bungesa district. The present study also indicates the very rich ethnozoological knowledge of these people in relation to traditional medicine. So there is a critical need to properly document to keep a record of the ethnozoological information. We hope that the information generated in this study will be useful for further research in the field of ethnozoology, ethnopharmacology and conservation approach.
\end{abstract}

Keywods: Ethnozoology, Traditional Medicine, Medicinal animals, Tanzania

\footnotetext{
* Correspondence: Vatsr71@gmail.com

School of Biological Sciences, College of Natural and Mathematical Sciences, the University of Dodoma, Dodoma, Tanzania
} 


\section{Background}

Faunal resources have played a wide range of roles in human life from the earliest days of recorded history. Human beings are familiar with use of animals and plants for food, cloth, medicine, etc. since ancient times $[1,2]$. The study of relationship between the human societies and the animal resources around them deals under Ethnozoology [3]. Since prehistoric time's animals, their parts, and products have created part of the inventory of medicinal substances used in numerous cultures [4]. The world health organization estimates that most of the world's population relies primarily on animal and plant based medicines [5]. Of the 252 indispensible chemicals that have been selected by the World Health Organization, 8.7\% derived from animals [6]. In Brazil, Alves et al. reported the medicinal use of 283 animal species for the treatment of various ailments [7]. In Bahia state, in the northeast of Brazil, over 180 medicinal animals have been recorded in traditional health care practices [8]. In Traditional Chinese Medicine more than 1500 animal species have been recorded to be some medicinal use [9]. Alves and Rosa recorded the use of 97 animal species as traditional medicine in urban areas of NE and N Brazil [10]. Lev and Amar conducted a survey in the selected markets of Israel and found 20 animal species, which products were sold as traditional drugs
[11]. Tamang people of Nepal identify the 11 animal species for used in zootherapeutic purposes [12]. Alves and Rosa in the North and north- east regions of Brazil carried out a survey in fishing communities and recorded 138 animal species, used as traditional medicine [13]. Alves et al. also reported nearly 165 reptile's species were used in traditional folk medicine around the world [14]. Alves conducted a review study in Northeast Brazil and lists 250 animal species for the treatment of diverse ailments [15]. Lev and Amar conducted a study in the selected markets in the kingdom of Jordan and identified 30 animal species, and their products were retailed as traditional medications [16]. In India use of traditional medicine are documented in works like Ayurveda and Charaka Samhita. A number of animals are mentioned in Ayurvedic system, which includes 41 Mammals, 41 Aves, 16 Reptiles, 21 Fishes and 24 Insects [17]. Different ethnic group and tribal people use animals and their products for healing practices of human ailments in present times in India [18]. In Hindu religion people used the various products obtained from the cow viz. milk, urine, dung, curd and ghee since ancient times [19].

Tanzania is gifted with immense faunal and floral biodiversity, because of the thrilling variation in geographical and climatic condition prevailing in the country. In

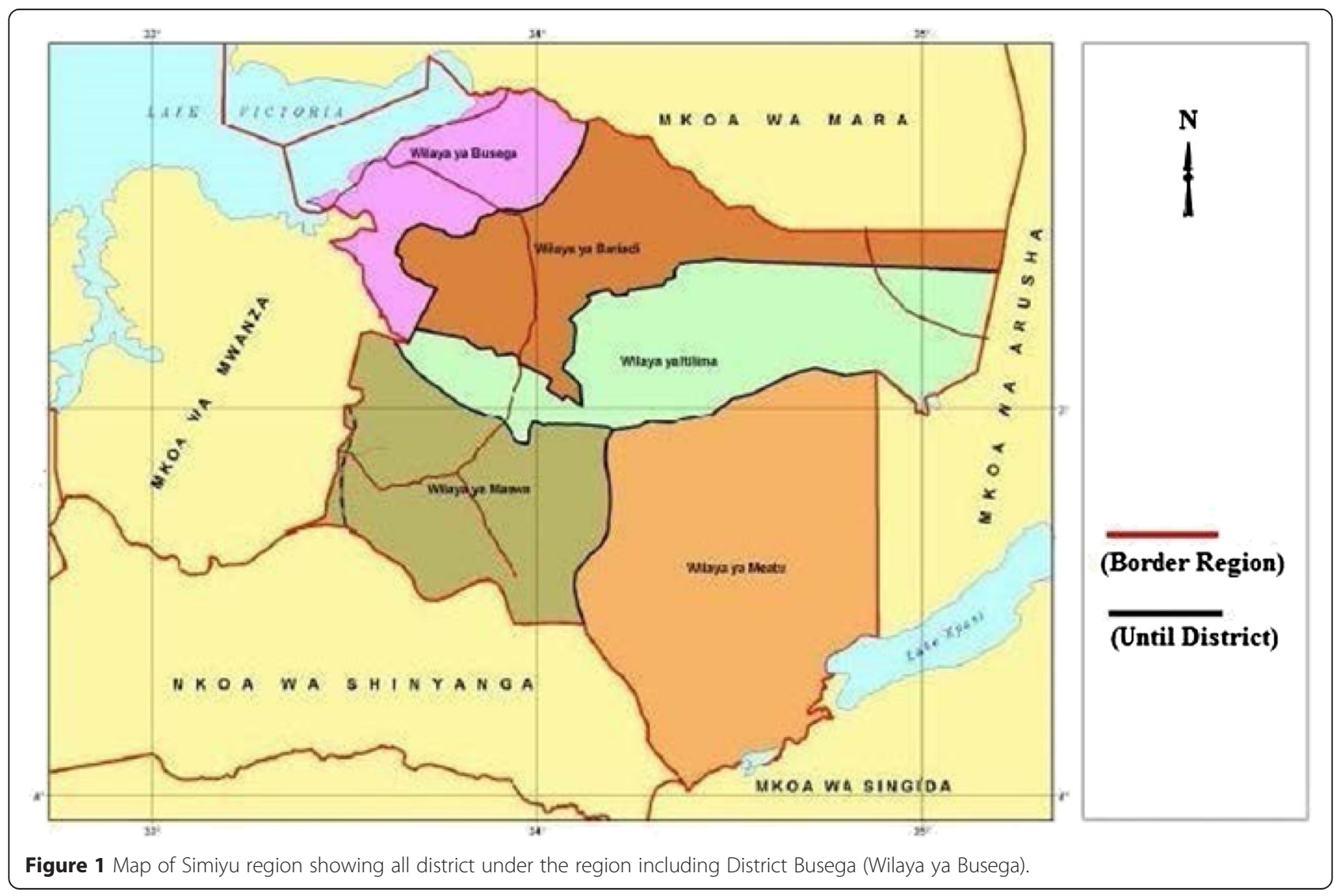




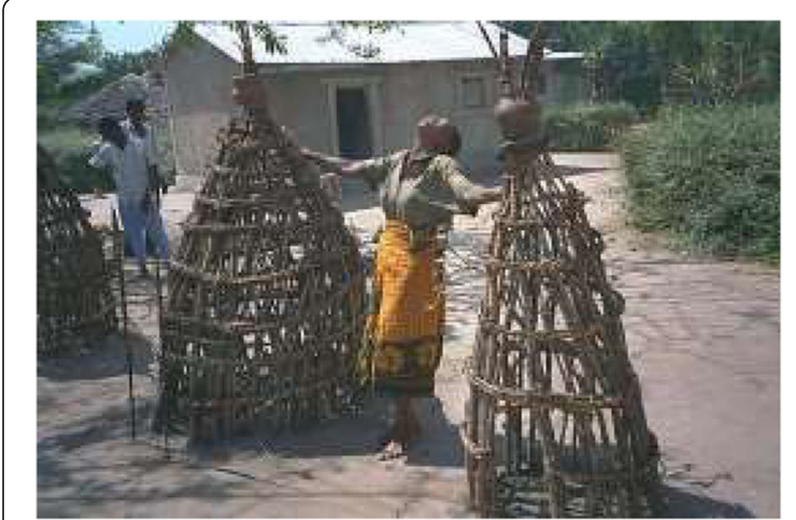

Figure 2 Sukuma lady doing traditional prayer.

Tanzania, traditional medicine has existed even before colonial times. It used to play a vital role in the doctrine of chiefdoms that existed during pre-colonial era. Colonialists, with their intension to rule Africa had to find a way to discourage all sort of activities which would have provided an opportunity for developing Africans [20]. In Tanzania, different tribal communities are dispersed all over the country, people of these communities are extremely knowledgeable about the animals and their medicinal value, and they also deliver extensive information about the use of animals and their by-products as medicine. Most of the tribal people are totally dependent on local traditional medicinal system for their health care because they are living in very remote areas where hospital and other modern medicinal facilities are not available and even negligible, so they use their traditional knowledge for medicinal purpose and this knowledge is passed through oral communication from generation to generation. It is estimated that more than $80 \%$ of the rural population in Tanzania depends on the traditional medicine [21].

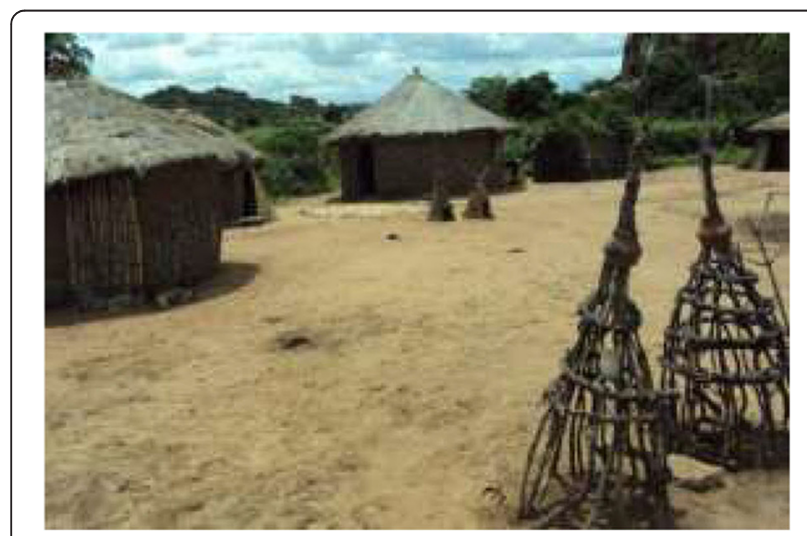

Figure 3 Ancestral shrines in a rural Sukuma healer's compound.

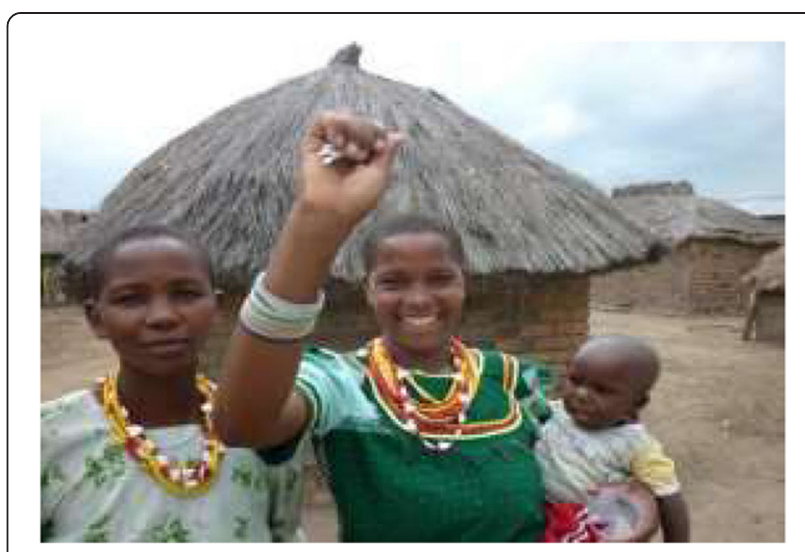

Figure 4 Sukuma lady with her children and traditional house.

A lot of work has been done on utilization of plants and their products as traditional and allopathic medicine in the world. Like plants, animal and their products also keep medicinal properties [22]. Most ethnobiological studies conducted in Tanzania have focused on traditional knowledge of plants and less in animals [23,24]. A little work has been done in Ethnozoology in Tanzania and particularly no work is documented in Sukuma tribe and there is a definite scarcity of ethnobiological knowledge when it comes to animal products. The present study briefly reports an ethnomedicinal/traditional medicinal study among Sukuma tribe in Bugusa district in Tanzania.

\section{Methods}

\section{The study area}

The intended study was carried out in Busega District at Simiyu region. The Busega district is one of five districts in Simiyu Region of Tanzania, namely, Meatu, Itilima, Bariadi, Maswa and Busega. Busega district is located on the northwestern part of Simiyu Region and shares borders with Magu districts in west, Bariadi districts in

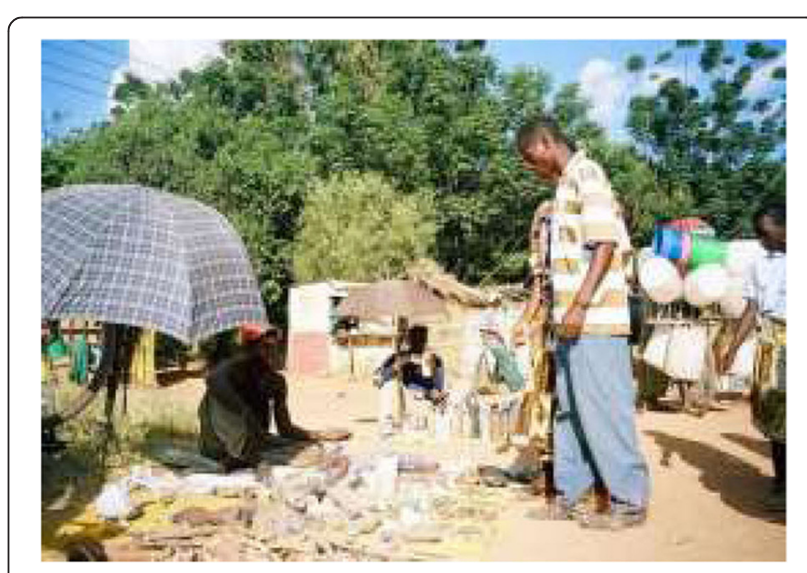

Figure $\mathbf{5}$ Traditional healers selling medicines in local market. 
Table 1 Knowledge of animal resource use among Sukuma Tribe of Busega District

\begin{tabular}{|c|c|c|c|c|c|c|c|c|c|c|}
\hline Scientific name & $\begin{array}{l}\text { Common name } \\
\text { (E) }\end{array}$ & $\begin{array}{l}\text { Local name } \\
\text { (S) }\end{array}$ & $\begin{array}{l}\text { Vernacu } \\
\text { lar name }\end{array}$ & Parts used & Traditional Uses & Mode of Preparation & Dosage & $\begin{array}{l}\text { Resp } \\
\text { onde nt }\end{array}$ & $\begin{array}{l}\text { Use } \\
\text { value }\end{array}$ & $\begin{array}{l}\text { Conserv } \\
\text { ation statu }\end{array}$ \\
\hline \multicolumn{11}{|l|}{ Mammals } \\
\hline \multirow[t]{3}{*}{$\begin{array}{l}\text { Eudorcas thomsonii } \\
\text { (Gunther, 1884) }\end{array}$} & \multirow[t]{3}{*}{$\begin{array}{l}\text { Thomson's } \\
\text { Gazelle }\end{array}$} & \multirow[t]{3}{*}{ Nyamela } & \multirow[t]{3}{*}{ mbushi } & \multirow[t]{3}{*}{$\begin{array}{l}\text { Heart Skin } \\
\text { Tail }\end{array}$} & $\begin{array}{l}\text { Treat: asthma, } \\
\text { Pneumonia Make } \\
\text { drums }\end{array}$ & Dry, grind pour hot water & \multirow[t]{3}{*}{$\begin{array}{l}\text { Inhale the smoke } \\
1 / \text { day }^{*} 4 \text { days }\end{array}$} & \multirow[t]{3}{*}{145} & \multirow[t]{3}{*}{0.80} & \multirow[t]{3}{*}{$\begin{array}{l}\text { Status: NT } \\
\text { Trend: D }\end{array}$} \\
\hline & & & & & Chase away insect & Mount flesh skin container & & & & \\
\hline & & & & & & Tail is being dried and used & & & & \\
\hline \multirow{2}{*}{$\begin{array}{l}\text { Hippopotamu s amphibious } \\
\text { (Linnaeus, 1778) }\end{array}$} & \multirow[t]{2}{*}{ Hippopotamus } & \multirow[t]{2}{*}{ Kiboko } & \multirow[t]{2}{*}{ ngubho } & \multirow[t]{2}{*}{ Blood } & \multirow{2}{*}{$\begin{array}{l}\text { Boost } \mathrm{CD}_{4} \text { for HIV } \\
\text { patient }\end{array}$} & \multirow[t]{2}{*}{ Blood dried for 3 days } & 3 spoons/day* & \multirow[t]{2}{*}{88} & \multirow[t]{2}{*}{0.48} & Status: VU \\
\hline & & & & & & & 30 days & & & Trend: D \\
\hline \multirow{2}{*}{$\begin{array}{l}\text { Equus quagga } \\
\text { (Boddaert, 1785) }\end{array}$} & \multirow[t]{2}{*}{ Plains Zebra } & \multirow[t]{2}{*}{ Pundamilia } & \multirow[t]{2}{*}{ ndolo } & \multirow[t]{2}{*}{ Hooves } & \multirow[t]{2}{*}{ Treat: glands } & \multirow[t]{2}{*}{ Burn, grind, mix with water } & \multirow{2}{*}{$\begin{array}{l}2 \text { cup/day*7 } \\
\text { days }\end{array}$} & \multirow[t]{2}{*}{122} & \multirow[t]{2}{*}{0.68} & Status: LC \\
\hline & & & & & & & & & & Trend: S \\
\hline $\begin{array}{l}\text { Atherurus africanus } \\
\text { (Gray, 1842) }\end{array}$ & Porcupine & Nungunungu & Nungu & Spines & Treat: abscess & Rub ashes in abscess & $2 /$ day $* 2$ days & 129 & 0.72 & $\begin{array}{l}\text { Status: LC } \\
\text { Trend: } U\end{array}$ \\
\hline $\begin{array}{l}\text { Crocuta crocuta } \\
\text { (Erxleben, 1777) }\end{array}$ & Spotted Hyena & Fisi & Mbiti & $\begin{array}{l}\text { Meat Skin } \\
\text { and Feaces }\end{array}$ & Treat :TB & Eat dry meat Cham & $\begin{array}{l}3 \text { pieces/day*3 } \\
\text { days. }\end{array}$ & 142 & 0.79 & Status: LC \\
\hline & & & & & For protection & & Tie on waist & & & Trend: D \\
\hline Ovis aries (Linnaeus, 1778) & red Maasai & Kondoo & Ng'oro & Fat & Treat: burn & Extract tail fat & Rub everyday & 105 & 0.58 & Status: NA \\
\hline & & & & & & & & & & Trend: $U$ \\
\hline Diceros bicornis & Black Rhinoceros & Faru & Mhela & Horn & Treat: asthma, & Paste the horn mix with hot & 2/ day* 30 days & 96 & 0.53 & Status: CR \\
\hline (Linnaeus, 1//8) & & & & & gastritis; |B & & & & & Trend: I \\
\hline Phataginus tricuspis & African Pangolin & Kakakuona & Murhuka & Scales & Goodluck & Make charms. & Tie on hand & 154 & 0.85 & Status: NT \\
\hline (Rafınesque, 1821) & & & & & & & & & & Trend: D \\
\hline Atelerix albiventris & Four-toed & Kalunguyeye & Kilungu & Skin; & Stop blood discharge & Burn; inhale its smoke & Time of suffering & 103 & 0.57 & Status: LC \\
\hline & & & & & & & & & & Trend: S \\
\hline Loxodonta Africana & African Elephant & Tembo & Mhole & Skin & Treat: hepatitis & Burn; get ashes & 3 spoon/day*7 & 2 & .17 & Status: VU \\
\hline & & & & & & & & & & Trend: I \\
\hline Mungos mungo & Banded & Nguchiro & Ng'ara & Nail & Treat: cough & Grind and smell & 2/day & 5 & .13 & Status: LC \\
\hline (Gmelin, 1/88) & Mongoose & & & & & & & & & Trend: S \\
\hline Procavia capensis & Rock Hyrax & Pimbi & Membe & Urine & Treat: Syphilis & Collect hyrax urinated soil; mix & 1 cup/day*7 & 4 & .3 & Status: LC \\
\hline & & & & & & & & & & Trend: U \\
\hline Rattus norvegicus & Brown Rat & Panya & Kitakilan & Whole & Protection of thieves & Dry the dead rat. and. & embed on & 48 & .82 & Status: LC \\
\hline & & & & & & & & & & Trend: $\mathrm{S}$ \\
\hline Kerivoula Africana & Tanzanian & Popo & Tunge & Whole & Treat : pneumonia & Burn and inhale the smoke & $1 /$ day*3 days & 7 & .37 & Status: EN \\
\hline & & & & & & & & & & Trend: D \\
\hline
\end{tabular}


Table 1 Knowledge of animal resource use among Sukuma Tribe of Busega District (Continued)

\begin{tabular}{|c|c|c|c|c|c|c|c|c|c|c|}
\hline Panthera leo (Linnaeus, 1778) & Lion & Simba & Shamba & $\begin{array}{l}\text { Adipose } \\
\text { tissue Skin }\end{array}$ & $\begin{array}{l}\text { Treat ear pus For } \\
\text { protection }\end{array}$ & Rub fat on the ears Make charm & $\begin{array}{l}1 / \text { day } * \text { days } \\
\text { Tie on neck }\end{array}$ & 11 & .62 & $\begin{array}{l}\text { Status: VU } \\
\text { Trend: D }\end{array}$ \\
\hline $\begin{array}{l}\text { Phacochoeru s africanus } \\
\text { (Gmelin, 1788) }\end{array}$ & Warthog & Ngiri & Ngere & Tusks & Treat stomach ulcers & Grind, mix with hot water & $\begin{array}{l}2 \text { cup/day *7 } \\
\text { days }\end{array}$ & 2 & .28 & $\begin{array}{l}\text { Status: LC } \\
\text { Trend: S }\end{array}$ \\
\hline $\begin{array}{l}\text { Lepus capensis } \\
\text { (Linnaeus, 1778) } \\
\text { Insect }\end{array}$ & Cape Hare & Sungura & Sayayi & Fur & For wound healing & Take the fur burn it and & $\begin{array}{l}\text { Rub ashes in } \\
\text { the wound. }\end{array}$ & 8 & .48 & $\begin{array}{l}\text { Status: LC. } \\
\text { Trend: D }\end{array}$ \\
\hline $\begin{array}{l}\text { Aglais urticae } \\
\text { (Linnaeus, 1778) }\end{array}$ & Butterfly & Kipepeo & Parapapu & Wings & Treat: chest pain. & Grind; Swallow powder & 3/day*5 days. & 5 & .25 & $\begin{array}{l}\text { Status: NA } \\
\text { Trend: U }\end{array}$ \\
\hline Lasius niger (Linnaeus, 1778) & Black ants & Chungu & Sungwa & $\begin{array}{l}\text { Whole } \\
\text { organism. }\end{array}$ & $\begin{array}{l}\text { To become intelligent } \\
\text { and leader }\end{array}$ & $\begin{array}{l}\text { Take the fore ant, grind and } \\
\text { rub on head }\end{array}$ & $1 /$ day*3 days & 29 & .72 & $\begin{array}{l}\text { Status: } \\
\text { LC Trend: S }\end{array}$ \\
\hline $\begin{array}{l}\text { Butastur rufipennis } \\
\text { (Sundevall, 1851) }\end{array}$ & $\begin{array}{l}\text { Grasshopper } \\
\text { Buzzard }\end{array}$ & Panzi & Ng'umbe & $\begin{array}{l}\text { Whole } \\
\text { organism }\end{array}$ & $\begin{array}{l}\text { Treat: stomachache; } \\
\text { heartbeat }\end{array}$ & $\begin{array}{l}\text { Burn, grind it into powdery } \\
\text { form. }\end{array}$ & $\begin{array}{l}\text { Rub } 2 / \\
\text { day*3 days }\end{array}$ & 54 & .86 & $\begin{array}{l}\text { S tatus: LC } \\
\text { Trend: D }\end{array}$ \\
\hline $\begin{array}{l}\text { Apis mellifera (Linnaeus, } \\
\text { 1778) }\end{array}$ & Honey bee & Nyuki & Nzoke & Honey & Treat: burn & Rub the burn & $2 /$ day $^{*} 3$ days & 38 & .76 & $\begin{array}{l}\text { Status: NA } \\
\text { Trend: U }\end{array}$ \\
\hline & Beetle & Kalilila & $\begin{array}{l}\text { Kombam } \\
\text { wiko }\end{array}$ & $\begin{array}{l}\text { Whole } \\
\text { organism }\end{array}$ & $\begin{array}{l}\text { Call a person to } \\
\text { come back home }\end{array}$ & $\begin{array}{l}\text { Burn beetle and call the name } \\
\text { of a person. }\end{array}$ & $3 /$ day $^{*} 3$ days & 48 & .82 & $\begin{array}{l}\text { Status: NA } \\
\text { Trend: U }\end{array}$ \\
\hline Chilopoda & & & & & & & & & & \\
\hline $\begin{array}{l}\text { Scutigera coleoptrata } \\
\text { (Linnaeus, 1778) }\end{array}$ & Millipede & Tandu & & Whole & Treat Dandruff & Burn and swallow the ashes. & $1 /$ day*3 days & 45 & .25 & $\begin{array}{l}\text { Status: NA } \\
\text { Trend: U }\end{array}$ \\
\hline Arachnida & & & & & & & & & & \\
\hline Araneus spp (Clerck, 1757) & Spider & Buibui & & Spider web & Stop bleeding. & Apply direct on fresh wound. & Once/ day & 99 & .55 & $\begin{array}{l}\text { Status: LC } \\
\text { Trend: S }\end{array}$ \\
\hline Diplopoda & & & & & & & & & & \\
\hline $\begin{array}{l}\text { Trigoniulus corallines } \\
\text { (Gervais, 1847) }\end{array}$ & Millipede & Jongoo & lgongoli & Whole body & Treat dandruff & Press plasma fluid and swallow & $2 /$ day $^{*} 2$ days & 2 & .51 & $\begin{array}{l}\text { Status: NA } \\
\text { Trend: U }\end{array}$ \\
\hline Reptiles & & & & & & & & & & \\
\hline $\begin{array}{l}\text { Naja siamensis } \\
\text { (Laurenti, 1768) }\end{array}$ & Cobra & Cobra & Kipele & Skin & $\begin{array}{l}\text { Treat: burns } \\
\text { fractured bone }\end{array}$ & $\begin{array}{l}\text { Powder the skin, mixed with } \\
\text { water }\end{array}$ & $\begin{array}{l}\text { Rub } 2 / \text { day*3 } \\
\text { days }\end{array}$ & 129 & .72 & $\begin{array}{l}\text { Status: VU } \\
\text { Trend: D }\end{array}$ \\
\hline $\begin{array}{l}\text { Agama mwanzae } \\
\text { (Loveridge, 1923) }\end{array}$ & $\begin{array}{l}\text { Flat-headed } \\
\text { Rock Agama }\end{array}$ & Mjusi & Madhore & Bile & Treat dysentery. & Drink flesh bile & $\begin{array}{l}1 \text { spoon/day*3 } \\
\text { days }\end{array}$ & 8 & .43 & $\begin{array}{l}\text { Status: LC } \\
\text { Trend:S }\end{array}$ \\
\hline $\begin{array}{l}\text { Python regius } \\
\text { (Shaw, 1802) }\end{array}$ & Royal Python & Chatu & Nsato & Feaces & Treat back pain & Mix with little water & $\begin{array}{l}\text { Rub on back } \\
2 / \text { day }^{*} 3\end{array}$ & 23 & .68 & $\begin{array}{l}\text { Status: LC } \\
\text { Trend: U }\end{array}$ \\
\hline
\end{tabular}


Table 1 Knowledge of animal resource use among Sukuma Tribe of Busega District (Continued)

\begin{tabular}{|c|c|c|c|c|c|c|c|c|c|c|}
\hline $\begin{array}{l}\text { Crocodylus niloticus } \\
\text { (Laurenti, 1768) }\end{array}$ & Nile Crocodile & Mamba & Ng'wina & Skin & Treat TB: gastritis. & Burn and swallow the ashes & $2 /$ day*7 days $^{*}$ & 78 & 0.43 & $\begin{array}{l}\text { Status: LC } \\
\text { Trend: S }\end{array}$ \\
\hline \multicolumn{11}{|l|}{ Aves } \\
\hline $\begin{array}{l}\text { Baleara reguloum } \\
\text { (Bennett, 1834) }\end{array}$ & $\begin{array}{l}\text { Grey Crowned } \\
\text { crane }\end{array}$ & Korongo & Izunya & blood & $\begin{array}{l}\text { Treat stomach } \\
\text { ulcers }\end{array}$ & Drink flesh blood & $3 /$ day*2 days & 117 & 0.65 & $\begin{array}{l}\text { Status: EN } \\
\text { Trend: D }\end{array}$ \\
\hline $\begin{array}{l}\text { Aquila rapax } \\
\text { (Temminck, 1828) }\end{array}$ & Tawny Eagle & Tai & Mbeshi & Feathers & Treat chest pain. & Burn and inhale the smoke & $\begin{array}{l}15 \text { minutes/ } \\
\text { day*3 days }\end{array}$ & 108 & 0.60 & $\begin{array}{l}\text { Status: LC } \\
\text { Trend: S }\end{array}$ \\
\hline $\begin{array}{l}\text { Gallus domesticus } \\
\text { (Linnaeus, 1778) }\end{array}$ & chicken & Kuku & Ng'oko & $\begin{array}{l}\text { Fat Egg } \\
\text { white }\end{array}$ & $\begin{array}{l}\text { Nasal congestion. } \\
\text { Treat: dysentery }\end{array}$ & $\begin{array}{l}\text { Rub the fat in the nasal Drink } \\
\text { egg white }\end{array}$ & $\begin{array}{l}\text { 3/day*3 days } \\
\text { Twice a day }\end{array}$ & 145 & 0.81 & $\begin{array}{l}\text { Status: NA } \\
\text { Trend: U }\end{array}$ \\
\hline $\begin{array}{l}\text { Threskiornis aethiopicus } \\
\text { (Latham, 1790) }\end{array}$ & $\begin{array}{l}\text { African Sacred } \\
\text { Ibis }\end{array}$ & $\begin{array}{l}\text { Nyangenyang } \\
\mathrm{e}\end{array}$ & Nzela & Blood & Treat: rheumatism & Drink flesh blood & $\begin{array}{l}1 / 2 \text { cup/day*7 } \\
\text { days }\end{array}$ & 59 & 0.32 & $\begin{array}{l}\text { Status: LC } \\
\text { Trend: D }\end{array}$ \\
\hline Ceryle rudis (Linnaeus, 1778) & Pied Kingfisher & $\begin{array}{l}\text { Ndobhelendo } \\
\text { bhele }\end{array}$ & & Fat & Treat: back pain & Massaged on the back & $2 /$ day $^{*} 4$ days & 142 & 0.79 & $\begin{array}{l}\text { Status: NT } \\
\text { Trend: D }\end{array}$ \\
\hline $\begin{array}{l}\text { Dendropicos stierlingi } \\
\text { (Reichenow, 1901) }\end{array}$ & $\begin{array}{l}\text { Stierling's } \\
\text { Woodpecker }\end{array}$ & Fulubeji & & $\begin{array}{l}\text { Intestinal } \\
\text { fecal content }\end{array}$ & Treat: diarrhea & $\begin{array}{l}\text { mix hot water with fecal } \\
\text { content }\end{array}$ & $\begin{array}{l}2 \text { cup/day*3 } \\
\text { days }\end{array}$ & 45 & 0.25 & $\begin{array}{l}\text { Status: NT } \\
\text { Trend: S }\end{array}$ \\
\hline $\begin{array}{l}\text { Anas indica } \\
\text { (Linnaeus, 1778) }\end{array}$ & Duck & Bata & Mbata & Fat & $\begin{array}{l}\text { Treat: Pneumonia, } \\
\text { Chest pain }\end{array}$ & $\begin{array}{l}\text { Wormed and massaged on } \\
\text { the chest }\end{array}$ & $3 /$ day $^{*} 3$ days & 92 & 0.51 & $\begin{array}{l}\text { Status: NA } \\
\text { Trend: } U\end{array}$ \\
\hline Fish & & & & & & & & & & \\
\hline $\begin{array}{l}\text { Mormyrus kannume } \\
\text { (Forsskal, 1758) }\end{array}$ & $\begin{array}{l}\text { Elephant snout } \\
\text { fish }\end{array}$ & Domodomo & Shironge & $\begin{array}{l}\text { Whole } \\
\text { organism }\end{array}$ & $\begin{array}{l}\text { Treat: hookworms; } \\
\text { removal poisonous }\end{array}$ & Burn, grind, mix with hot water & $\begin{array}{l}1 \text { cup/day*3 } \\
\text { days. }\end{array}$ & 169 & 0.94 & $\begin{array}{l}\text { Status: LC } \\
\text { Trend: D }\end{array}$ \\
\hline $\begin{array}{l}\text { Lates niloticus } \\
\text { (Linnaeus, 1778) }\end{array}$ & Nile Perch & Sangara & Mbuta & Gills & $\begin{array}{l}\text { Treat: abdominal } \\
\text { cramp }\end{array}$ & Pound and mix with water & $\begin{array}{l}1 \text { cup/day*7 } \\
\text { days }\end{array}$ & 85 & 0.47 & $\begin{array}{l}\text { Status: LC } \\
\text { Trend: } U\end{array}$ \\
\hline $\begin{array}{l}\text { Oreochromis variabilis } \\
\text { (Boulenger, 1906) }\end{array}$ & Victoria tilapia & Sato & Sato & Scales & Treat: cough & Burn and swallow the ashes & Regularly. & 145 & 0.81 & $\begin{array}{l}\text { Status: CR } \\
\text { Trend: D }\end{array}$ \\
\hline $\begin{array}{l}\text { Octopus vulgaris } \\
\text { (Cuvier, 1797) }\end{array}$ & $\begin{array}{l}\text { Common } \\
\text { octopus }\end{array}$ & Pweza & Naghala & Tail & $\begin{array}{l}\text { Treat: Urinary } \\
\text { retention }\end{array}$ & Burn and swallow its ashes & $2 /$ day $^{*} 3$ days & 25 & 0.13 & $\begin{array}{l}\text { Status: NA } \\
\text { Trend: } U\end{array}$ \\
\hline Gastropod & & & & & & & & & & \\
\hline Snail (O.F. Muller, 1774) & Achatina fulica & Konokono & Nonga & Shell & $\begin{array}{l}\text { Treat: leg pain; } \\
\text { make chain }\end{array}$ & Burn, grind, mix with water & $\begin{array}{l}\text { Rub 2/day *3 } \\
\text { days }\end{array}$ & 132 & 0.73 & $\begin{array}{l}\text { Status: NA, } \\
\text { Trend: U }\end{array}$ \\
\hline Oligochaeta & & & & & & & & & & \\
\hline $\begin{array}{l}\text { Lumbricus terrestris } \\
\text { (Linnaeus, 1778) }\end{array}$ & Earthworm & Mnyoo & & Whole & Treat impotence & Dry; paste mix with hot water & $\begin{array}{l}2 \text { spoon/day } \\
* 7 \text { days }\end{array}$ & 99 & 0.55 & $\begin{array}{l}\text { Status: NA } \\
\text { Trend: U }\end{array}$ \\
\hline
\end{tabular}


south, The southeastern part is covered by the Serengeti game reserve and Bunda district. In north side it bordered with Lake Victoria. As a result, many community members utilize both aquatic and terrestrial organisms as a source of medicine.

Busega district is located between latitude $2^{0} 10^{\prime}$ and $2^{0} 50^{\prime}$ South and between longitude $33^{\circ}$ and $34^{\circ}$ East. The district headquarter is in Nyashimo town. The district is divided into thirteen (13) wards and fifty four (54) villages as per Tanzania Population and Housing Census 2012 [25]. Busega district is Tropical in nature with sun overhead of equator on March and October. Temperature is tropical and range between $25^{\circ} \mathrm{C}$ and $30^{\circ} \mathrm{C}$ with average annual temperature of $27^{\circ} \mathrm{C}$. There are two wet seasons, the long rains from mid-March to early June, during which the precipitation is between $700 \mathrm{~mm}$ to $1000 \mathrm{~mm}$ and averages $800 \mathrm{~mm}$ per annum and short rains from October to December, during which the rainfall is between $400 \mathrm{~mm}$ to $500 \mathrm{~mm}$ [26]. Figure 1: Map of the study area.

\section{The Sukuma tribe}

The Sukuma are a patrilineal society; the role of the women being to take care of their husbands and children while men are overseer of the family $[27,28]$. Young people marry only when they are ready to carry the responsibilities marriage entails. They are initiated into adulthood in a ceremony known as "lhane". The Sukuma do not practice circumcision as part of initiation, but organize a separate ceremony. The young people involved in "lhane" have to be prepared well. Respected elders of the community tutor the initiates on their roles and responsibilities in the family and the whole community. The initiates have to think, act and participate as adults in all rituals. After "lhane" the initiates are considered adults and cannot be asked to deliver messages anywhere as this is a job for non-initiates [28].

The Sukuma are believed to being very superstitious, and most will seek aid from the "Bafumu", "Balaguzi" and "Basomboji" locally used to refer as medicine men, diviners and sooth sayers, respectively. The Basukuma have many stories based on their beliefs on death and sufferings. Traditional healers believe that fate is determined by "Shing'wengwe" and "Shishieg'we", that is ogres and spirits. The ogres are usually shown as being half human, half demon, or as terrible monsters [28]. The economic condition of the Sukuma people is not good. Agriculture, animal husbandry; poultry forming and laboring are source of income. Educational level is also found very low. The life of the people are full of traditions and social customs from birth to death owning to outdated customs, not attuned to remain competitive in the current economic scenario of privatization [Figures 2, $3,4,5]$.

\section{Procedures}

In order to obtain ethnozoological information about animal and their products used in traditional medicine, a study was conducted from August 2012 to July 2013 in the Busega district of Simiyu region, Tanzania. The ethnomedicinal data (local name of animals, mode of preparation and administration) were collected through semi-structured questionnaire (in their local language mainly Kiswahili, with the help of local mediator), interview and group discussion with selected people of the tribe. The selection of informants was based on their experience, recognition as expert and knowledge old aged person concerning traditional medicine. A total of 180 (118 male and 62 female) people were selected to collect ethnozoological information, these information were collected from local traditional healers, farmers, fisherman and cultural officer. We interviewed 98 (55\%) informants within age group 55 and above, followed by 42 informants (23\%) with 45 to 54 age group and 40 (22\%) with $35-44$ years age group.

They were inquired, about the illnesses cured by animal based medicines and the manner in which the medicines were prepared and administered. They were also requested thorough information about mode of preparation and blending of animal products used as ingredients and whether they use animal in the healing practice, since this type of information indicate how a given medicine can be therapeutically effective in term of the right ingredients, the proper dose and the right length of medication. The name of animals and other related information to this study were documented. Some pictures of Sukuma people at their local place and in their life style in study area were taken.

As stated by them, their traditional ethnozoological acquaintance was mainly attained through parental heritage and experience about medicinal value of animal to heal their families or themselves. The scientific name

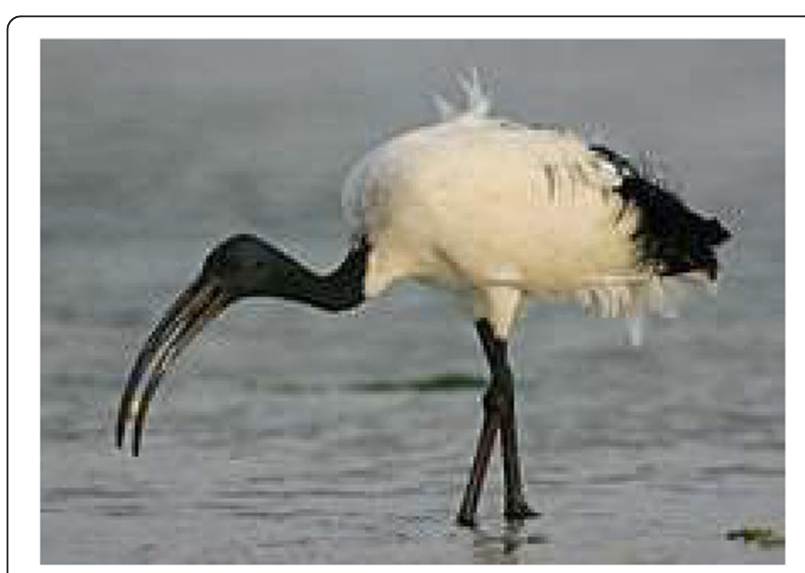

Figure 6 Threskiornis aethiopicus. 


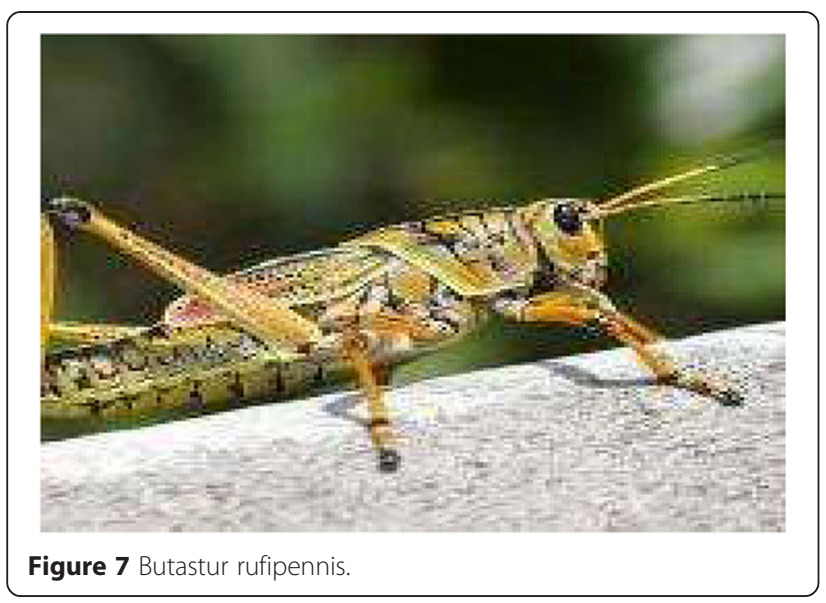

and species of animals were identified using relevant and standard literature $[29,30]$.

\section{Data analysis}

For the data analysis, fidelity level (FL) calculated that demonstrates the percentage of respondents claiming the use of a certain animal species for the same illnesses, was calculated for the most frequently reported diseases or ailments as:

$$
\mathrm{FL}(\%)=\mathrm{Np} \times 100 / \mathrm{N}
$$

Where $\mathrm{Np}$ is the number of respondents that claim a use of a species to treat a specific disease, and $\mathrm{N}$ is the number of respondents that use the animals as a medicine to treat any given disease [31]. The range of fidelity level (FL) is from $1 \%$ to $100 \%$. High use value (close to $100 \%$ ) show that this particular animal species are used by large number of people while a low value show that the respondents disagree on that spices to be used in the treatment of ailments.

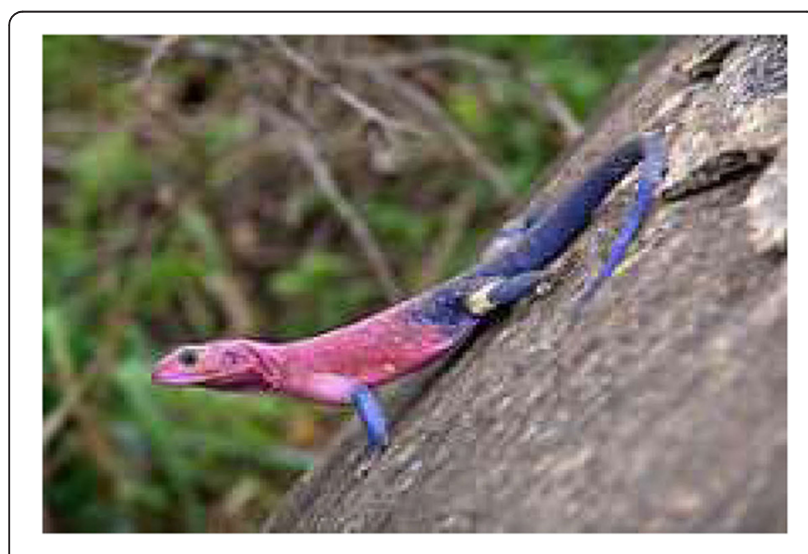

Figure 8 Agama Mwanzae.

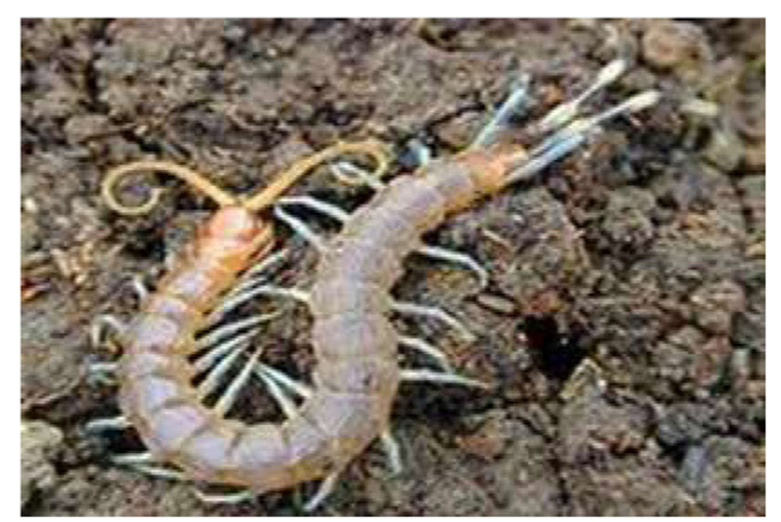

Figure 9 Trigoniulus corallines.

\section{Result and discussion}

The present study revealed the traditional medicinal knowledge of treating many types of ailments using different animal and their products by the local Sukuma people inhabitants of Simuyu region, Tanzania. Many old generation people were found to lack formal education, but they have acquaintance about use of local faunal and floral resources for traditional medicinal and other purposes [12], Sukuma people are one of them [Table 1].

The Table 1 shows that, Sukuma people of Busega district were using 42 animal species for the treatment of over 30 different kinds of illnesses. The animal species used as traditional medicine by these people comprise of seventeen mammals, seven birds, four reptiles, eight arthropods and two mollusks species. Highest number of animal belonged to mammalian taxonomic group $(n=17,41 \%)$, birds $(n=7,17 \%)$, reptiles $(n=4$, $9.5 \%)$, fishes $(n=4,9.5 \%)$ and arthropods $(n=8,19 \%)$ respectively. Sukuma people use these animal and their products for the treatment of more than 30 types of different illnesses including asthma, paralysis, cough,

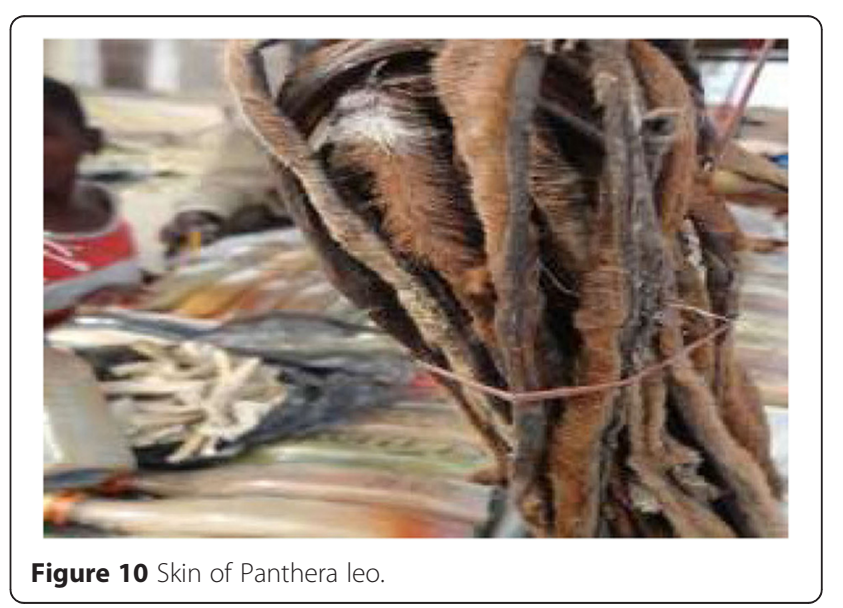




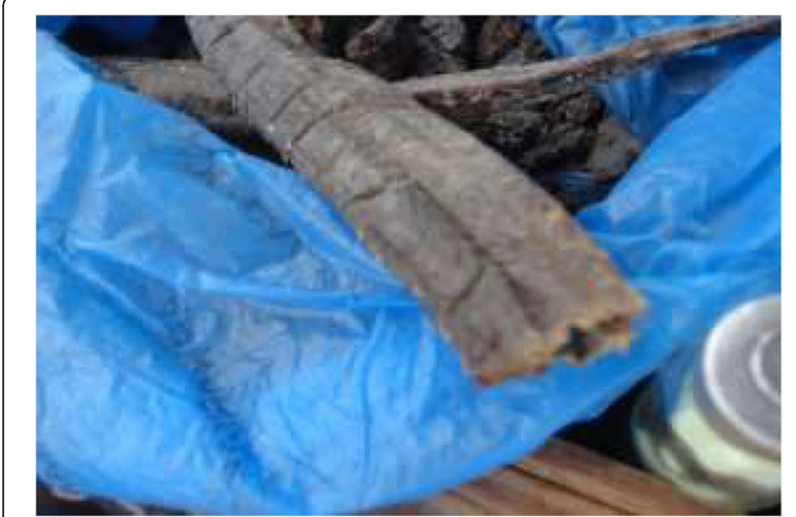

Figure 11 Dried Mormyrus kannume.

fever, cold, STD, wound healing etc. These animals were used as whole or byproducts of these animals like milk, blood, organ, flesh, tooth, urine, honey, feather etc. for the treatment of various illnesses and used in the preparations of traditional medicine [Figures 6, 7, $8,9,10,11,12,13]$.

Fidelity levels (FL) demonstrate the percentage of respondents claiming the use of a certain animals for curing of the illness. The uses of animals that are generally known by the Sukuma respondents have higher fidelity level is shown in Table 1.

Table: 1 also shows that cough, Tuberculosis, asthma, and other respiratory diseases are most frequently quoted disease among Sukuma people, as such, a number of traditional medicine are available for the treatment of such diseases, many animal byproducts were used like flesh of gazelle, horn of rhino, nail of mungos, and honey are some of them. Another important aspect of the present study that needs to be mentioned is that the Sukuma people also use some endangered, vulnerable and near threatened animal species as medicinal resources. A total of 42

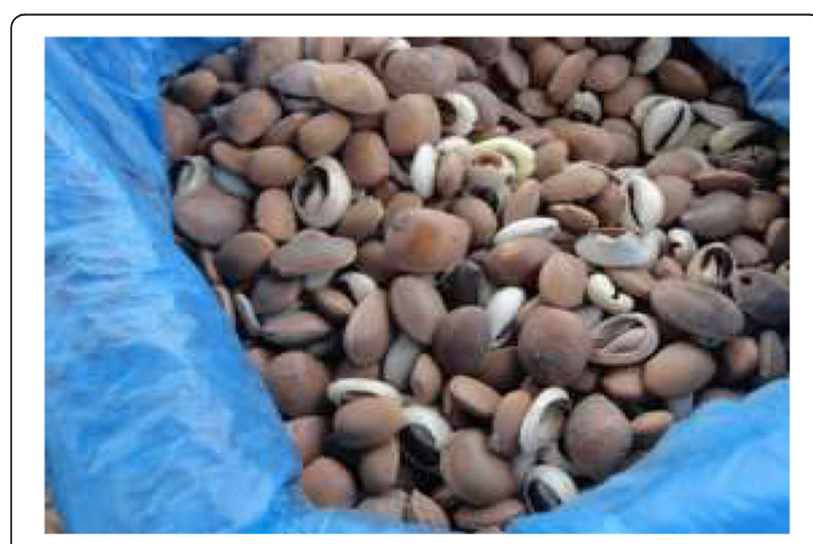

Figure 12 Achatina Fulica Shell.

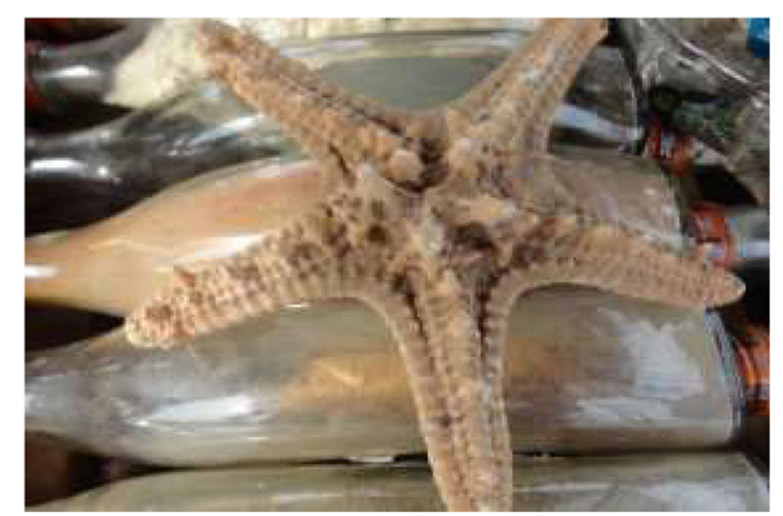

Figure 13 Dried Asterias sp.

identified animal species, of which 12 (28.57\%) are included in the IUCN Red Data list [32]. It is important to mention here that species such as Tanzanian woolly bat, grey crowned crane, are listed as endangered while Black rhino and Victoria tilapia are listed as critically endangered and hippopotamus, African elephant, Simba (Panthera leo), Cobra (Naja siamensis) are listed as vulnerable in IUCN Red Data list. These tribal people have scarce knowledge, many irrational belief and myths associated with customs that cause harm to animal life. Thus these traditional medicine and animals byproducts should be tested for their appropriate medicinal components, if cited animal species among these people, byproducts of these animals, were used in the treatment of various illnesses.

Sukuma people also use one animal product with other animal products or plant derivatives to found indefensible, the people should be aware about the endangered and protected animal species and their importance in biodiversity. Consequently, the socioecological system has to be strengthened through sustainable management and conservation of biodiversity [33] [Table 2].

Main threats of conservations in Tanzania includes overexploitation of natural resources due to poverty, rapid human population growths, weak wildlife policy and legislations, habitat alterations as well as inadequate funding. Poaching or illegal off take of wildlife resources has gone continuously regardless of wildlife

Table 2 Conservation status of animal utilized in traditional medicine

\begin{tabular}{lcc}
\hline IUCN red list category $\mathbf{2 0 1 3}$ & Frequency & Percent \\
\hline Least concern & 20 & 47.62 \\
Near threatened & 04 & 9.52 \\
Vulnerable & 04 & 9.52 \\
Endangered & 02 & 4.76 \\
Critically endangered & 02 & 4.76 \\
\hline
\end{tabular}




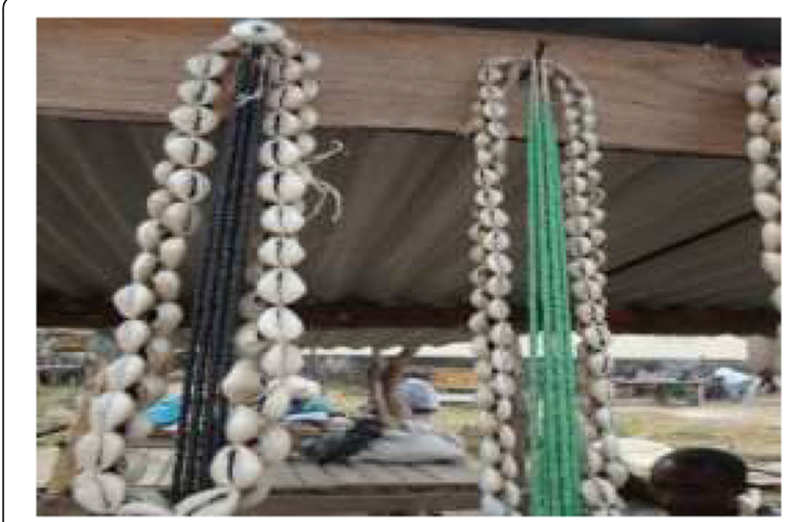

Figure 14 Different products obtained from animal resources among Sukuma Tribes.

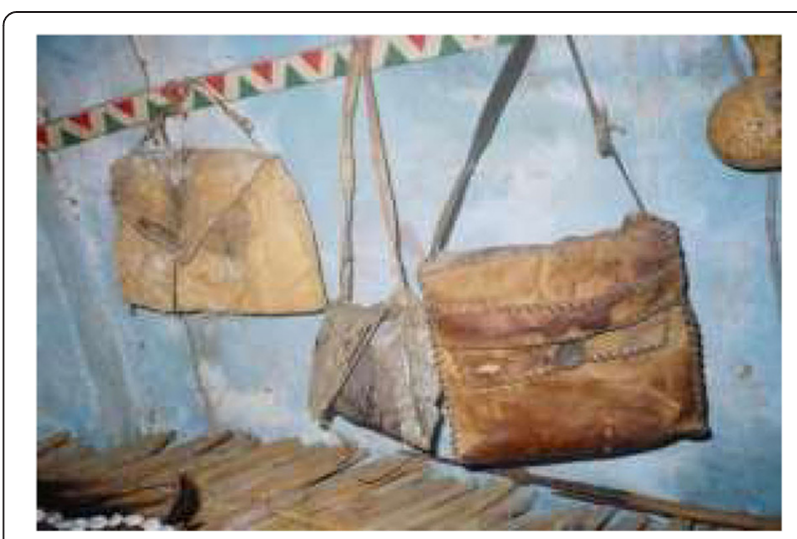

Figure 16 Different products obtained from animal resources among Sukuma Tribes. conservation laws. However, traditional hunters in Tanzania have not been serious threat to wildlife. Wildlife populations are threatened by commercial poaching in which animal are used in bush meat trade and traditional medicine [34]. Despite medicinal purpose, Sukuma people also use animal resources for other purpose in their daily life. The Sukuma people use slough (molted skin of various animals) to decorate their traditional houses and this type of decoration are also reported in many other tribes living in other parts of Tanzania [Figures 14, 15, 16, 17].

\section{Conclusion}

The current study shows that forty two animals were found to be used among Sukuma tribe of Busega district. Twelve animal species are officially considered as threatened species by IUCN red list (2012) were found among the set of faunistic resources prescribed as

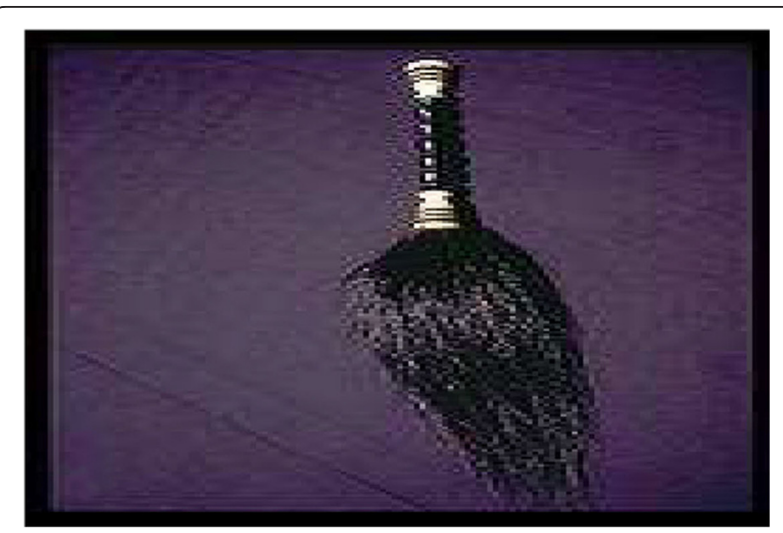

Figure 15 Different products obtained from animal resources among Sukuma Tribes. medicines at the time of this research. The latter author noted that Sukuma healers who are also diviners are more likely to use both wild and domesticated animals in their diagnoses. Moreover mammals, reptiles, birds, fish, and amphibians have been used in the field of traditional medicine for different purposes. However, mammals seem to be used much $(40.50 \%)$ compare to other group among Sukuma tribe, followed by aves (16.7\%). Amphibians are not commonly used in Sukuma society.

The present study also shows that the Sukuma people have very rich folklore and traditional knowledge in the utilization of different animal. So there is an urgent need to properly document to keep a record of the ethnomedicinal data of animal products and their medicinal uses. More studies are prerequisite for scientific validation to endorse medicinal value of such products and to include this knowledge in policies of conservation

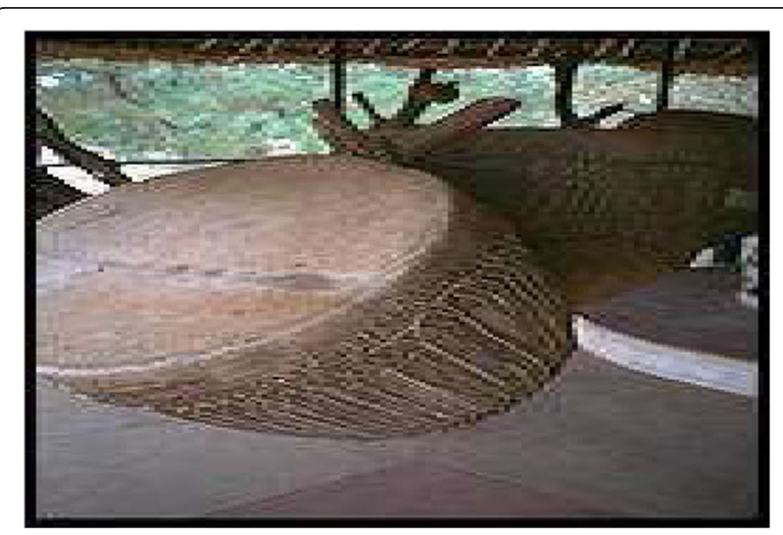

Figure 17 Different products obtained from animal resources among Sukuma Tribes. 
and management of animal resources. We hope that the present information will be helpful in further research in the field of ethnozoology, ethnopharmacology and biodiversity conservation viewpoint.

\section{Competing interests}

The authors declare that they have no competing interests.

\section{Authors' contributions}

All authors had significant intellectual contribution towards the design of the field study, data collection, data analysis and write-up of the manuscript. Both authors read and approved the final manuscript.

\section{Acknowledgements}

Authors are thankful to the Head and Dean of Biological sciences for providing all facilities and reinforcements during the study. We are also highly grateful to all the respondents who shared their traditional ethnozoological knowledge and permitted us to take pictures. Without their involvement, this study would have been impossible.

Received: 14 May 2014 Accepted: 17 January 2015

Published online: 07 May 2015

\section{References}

1. Alves RRN. Relationships between fauna and people and the role of ethnozoology in animal conservation. Ethnobiol Conserv. 2012;1(2):1-69.

2. Judith H: Information Resources on Human-Animal Relationships Past and Present. AWIC (Animal Welfare Information Center). Resource Series No. 30 2005

3. Lohani U, Rajbhandari K, Shakuntala K. Need for systematic ethnozoological studies in the conservation of ancient knowledge system of Nepal - a review. Indian J Tradit Knowl. 2008:7(4):634-7.

4. Lev E. Traditional healing with animals (zootherapy): medieval to presentday Levantine practice. J Ethnopharmacol. 2003:85:107-18.

5. WHO/IUCN/WWF: Guidelines on Conservation of Medicinal Plants. Switzerland 1993.

6. Marques JGW. Fauna medicinal: recurso do ambiente ou ameaça à biodiversidade? Mutum. 1997;1(1):4

7. Alves RRN, Rosa IL, Santana GG. The q in Brazil. Bio Sci. 2007:57(11):949-55.

8. Costa-Neto EM. Implications and applications of folk zootherapy in the state of Bahia. Northeastern Brazil Sustain Dev. 2004:12(3):161-74.

9. China National Corporation of Traditional and Herbal Medicine. Materia medica commonly used in China Beijing. China Beijing: Science Press; 1995.

10. Alves RRN, Rosa IL. Zootherapy goes to town: The use of animal-based remedies in urban areas of NE and N Brazil. J Ethnopharmacol. 2007; 113:541-55.

11. Lev E, Amar Z. Ethnophrmacological survey of traditional drugs sold in Israel at the end of the 20th century. J Ethnopharmacol. 2000;72:191-205.

12. Tamang G. An ethnozoological study of the Tamang people. Our Nat. 2003;1:37-41.

13. Alves RRN, Rosa IL. Zootherapeutic practices among fishing communities in North and Northeast Brazil:a comparison. J Ethnopharmacol. 2007;111:82-103.

14. Alves RRN, Vieira WL, Santana GG. Reptiles used in traditional folk medicine: conservation implications. Biodivers Conserv. 2008;17(1):2037-49.

15. Alves RRN. Fauna used in popular medicine in Northeast Brazil. J Ethnobiol Ethnomed. 2009;5:1.

16. Lev E, Amar Z. Ethnophrmacological survey of traditional drugs sold in the kingdom of Jordan. J Ethnopharmacol. 2002:82:131-45.

17. Tripathy BB. Drabya Guna Kalpa Druma, Orissa (Vols. I \& II). Publ. D.P. Tripathy, Bellaguntha (Ganjam District), 51995

18. DP Jaroli DP, Mahawar MM, Vyas N. An ethnozoological study in the adjoining areas of Mount Abu wildlife sanctuary. J Ethnobiol Ethnomed. 2010;6(6):1-9.

19. Simoons FJ. The purification rule of the five products of the cow in Hinduism. Ecol Food Nutr. 1974:3:21-34.
20. Mbwambo ZH, Mahunnah RA, Kayombo EJ. Traditional health practitioner and the scientist: bridging the gap in contemporary health research in Tanzania. Tanzania Health Res Bull. 2007;9(2):115-20.

21. Traditional Medicine Strategy 2002-05, WHO/EDM/TRM2002.1, 2002, WHO, Geneva, Switzerland

22. Oudhia P. Traditional knowledge about medicinal insects, mites and spiders in Chhattisgarh. India: Insect Environment; 1995.

23. Kisangau DP, Lyaruu HVM, Hosea KM, Joseph CC. Use of traditional medicines in the management of HIV/AIDS opportunistic infections in Tanzania: a case in the Bukoba rural district. J Ethnobiol Ethnomed. 2007;3(1):29. Doi: 10.1186/1746-4269-3-29.

24. Clack TAR. Culture, History and Identity: Landscapes of Inhabitation in the Mount Kilimanjaro Area, Tanzania, Essays in honour of Paramount Chief Thomas Lenana Mlanga Marealle II (1915-2007) BAR International Series 1966. 2009.

25. United Republic of Tanzania (URT). Traditional and Alternative Medicine Act No. 23 of 2002, United Republic of Tanzania. Dar es Salaam: Government Printer; 2002

26. De Rwetabula JF, Smedt RM, Mwanuzi F. Transport of micro pollutants and phosphates in the Simiyu River (tributary of Lake Victoria), Tanzania. In: Submitted and presented at The 1st International Conference on Environmental Science and Technology, New Orleans, Louisiana, USA January 23-26th. 2004. p. 2005.

27. Cory H. Sukuma law and custom. London: Oxford University Press; 1953.

28. Birley MH. Resource Management in Sukumaland, Tanzania, Africa. J Int Afr Inst. 1982;52:1-30.

29. Ali S. The book of Indian Birds. Bombay: Bombay: Natural History Society; 1996.

30. Prater SH. The Book of Indian Animals. Bombay: Bombay Natural History Society; 1996.

31. Alexiades MN. Selected Guidelines for Ethnobotanical Research: A Field Manual, Advances in Economic Botany Bronx: The New York Botanical Garden. 1996. p. 10

32. The IUCN Red List of Threatened species. 2009, http://www.Iucnredlist.org

33. Kakati LN, Bendang A, Doulo V. Indigenous knowledge of zootherapeutic use of vertebrate origin by the Ao Tribe of Nagaland. J Hum Ecol. 2006;19(3):163-7.

34. Severre EM. Conservation of wildlife outside core wildlife protected areas in the new millennium, millennium conference. Mweka, Tanzania: College of African Wildlife Management; 2000

\section{Submit your next manuscript to BioMed Central and take full advantage of:}

- Convenient online submission

- Thorough peer review

- No space constraints or color figure charges

- Immediate publication on acceptance

- Inclusion in PubMed, CAS, Scopus and Google Scholar

- Research which is freely available for redistribution

Submit your manuscript at www.biomedcentral.com/submit
C Biomed Central 